\section{Global Journal of Business, Economics and Management: Current Issues}

Volume 07, Issue 3 (2017) 275-284
Global Journal of

Business,Economics and Management: Current Issues

\title{
Development trends of socially responsible investment funds: View from Poland
}

\author{
Aleksandra Sulik-Górecka*, Department of Accounting, Faculty of Finance and Insurance, University of \\ Economics in Katowice, 1 Maja 50, 40-287 Katowice, Poland \\ Jolanta Rubik, University of Politechnika Częstochowska, Faculty of Mechanical Engineering and Computer \\ Science, Generała Jana Henryka Dąbrowskiego 69, 42-201 Częstochowa, Poland
}

\section{Suggested Citation:}

Sulik-Górecka, A. \& Rubik, J. (2017). Development trends of socially responsible investment funds. View from Poland. Global Journal of Business, Economics and Management: Current Issues. 7(3), 275-284.

Received June 6, 2017; revised August 17, 2017; accepted November 20, 2017.

Selection and peer review under responsibility of Prof. Dr. Gulzhanat Tayauova, Almaty Management University, Almaty, Kazakhstan.

C2016 SciencePark Research, Organization \& Counseling. All rights reserved.

\begin{abstract}
The issue of socially responsible investment (SRI) has been gaining increasing popularity in recent years. The idea of responsible investment, along with sustainable development, primarily assumes complying with ethical principles. The aim of this study is to survey the extent to which investment funds in Europe and Poland are guided by SRI. The criteria for identifying SRI funds are analysed, and their net asset value against the background of all investment funds in Europe is examined. The range of activities of SRI funds in Poland, which is surprisingly low, is also investigated. This paper uses the review method of legal regulations and analysis of the results of published studies concerning SRI funds. The results of the study confirm the growing importance of socially responsible funds in Europe. This paper is also a call for uniform reporting standards, so that SRI funds are more easily benchmarked against other investment funds.
\end{abstract}

Keywords: Socially responsible investment funds, sustainable development, RESPECT index, financial reporting.

\footnotetext{
* ADDRESS FOR CORRESPONDENCE: Aleksandra Sulik-Górecka, Department of Accounting, Faculty of Finance and Insurance, University of Economics in Katowice, 1 Maja 50, 40-287 Katowice, Poland

E-mail address: sulik gorecka@ue.katowice.pl
} 
Sulik-Górecka, A. \& Rubik, J. (2017). Development trends of socially responsible investment funds. View from Poland. Global Journal of Business, Economics and Management: Current Issues. 7(3), 275-284.

\section{Introduction}

The level of wealth in a given country and its society's affluence are reflected, among other things, in the degree of development of the financial system. Investment funds are important participants in the financial system of a country. Financial institutions that make up the financial system, including investment funds, should fulfil various functions to ensure the smooth functioning of the financial system.

A sample resource allocation function is implemented in investment funds, which allow individuals and institutional investors for an optimal allocation of the surplus capital held. The financial system is required to perform the function of effective management and risk control, so investment funds should implement the investment policy of the fund through the construction of an appropriate portfolio of assets. Moreover, investment funds are required to carry out the next function of creating clearing and payment systems for exchange of goods, services and assets. The function of pooling resources of individual investors for effective investment is clearly realised. It should be noted that investment funds should meet the penultimate function of providing information on the price. Investment funds should treat information on the basis of which investment decisions are made as a public good, thus ensuring the accuracy, reliability and relevance of publicly available information. The provision of reliable information is connected to the last function of the financial system, undertaken by investment funds, such as investor protection (Zamojska, 2012).

According to Khorana, Servaes and Tufano (2005) and Borowski (2011), the most important determinants influencing the development of investment funds include legal and tax factors, economic factors as well as socio-demographic factors The efficiency of legal institutions influencing the stability of the financial system of the country, the level of investor protection, the effectiveness of enforcement of these rights and the applied accounting standards are the legal and tax factors for the development of funds. The economic factors are related to the wealth of society in search of ways to invest the accumulated surplus of capital. The growth possibilities of investment funds are very strongly determined by macroeconomic factors such as economic growth rate, interest rate level and inflation level.

In recent years, new factors affecting the development of investment funds have emerged in the financial markets-they are related to the idea of sustainable investments. Both private and institutional investors, in addition to economic or legal and tax factors, have also begun to take into account social and ecological ones.

The aim of this paper is to explore the potential impact of sustainable investment on the development of investment funds. In particular, the objective is to describe criteria for identifying socially responsible investment (SRI) funds and to assess the extent to which investment funds in Europe are guided in their activity by SRI. The net asset value of SRI funds against the background of all investment funds in Europe was adopted as a measure. This paper also analyses the presence and scope of SRI funds in Poland, using the review of legal regulations and the analysis of the results of published studies concerning SRI funds.

\section{Criteria for Identifying Socially Responsible Investment Funds-A Literature Review}

According to Utz and Wimmer (2014), SRI emerged in the 1960s as a niche for altruists and philanthropists. Moreover, the authors noted that SRI manages $\$ 3.74$ trillion worth of assets in the USA and \$13.57 trillion worldwide.

Social responsibility involves complying with ethical principles. According to Biadacz and Borowiec (2017), the essence of social responsibility is 'more ethical, responsible and multifaceted behaviour of businesses towards social groups and environment that they interact with through their activities'. Among organisations promoting sustainable development through European financial markets, European Sustainable Investment Forum (Eurosif) is a leading player. Eurosif was founded in 2001 and 
acts as a partnership for sustainable investment forums in France, Germany, Italy, the Netherlands, the United Kingdom, Belgium, Spain and Sweden, with the support and involvement of member organisations. These include institutional investors, providers of financial services and academic institutions. Both Eurosif and other organisations supporting responsible investment (RI), such as the Social Investment Forum or the European Fund and Asset Management Association, emphasize that the concept of $\mathrm{RI}$ assumes the consideration of environmental, social factors and corporate governance in investment decisions, while ensuring balanced financial returns. The idea of RI is broadly discussed in Haigh and Hazelton (2004), Mallett and Michelson (2010) and Sakuma and Louche (2008).

The terms SRI and RI are used interchangeably. SRI funds are expected to take into account the socalled environmental, social, governance (ESG) factors in asset portfolio decisions. It is anticipated that these funds will invest, inter alia, in companies that meet the principles of social responsibility.

In practice and in the literature, different SRI qualification criteria are used, but according to Eurosif, they are most often based on different types of strategies used in investment decisions. These strategies include best-in-class, exclusions, norms-based screening, engagement and voting, ESG integration, sustainability themed and impact investing (Eurosif, 2016). For example, the SRI fund that selects the best-in-class strategy invests in the oil or gas sector, but only in those companies that are the best in a given industry. Focusing on the next strategy - the sustainability themed-the fund selects investments with a close link to sustainable development. Sustainability themed strategies include, but are not limited to, renewable energy, energy efficiency, sustainable transport, building sector, land use/forestry/agriculture, water management and waste management. In line with the next strategy-norms-based screening-investors assess the degree to which each company in their portfolio respects the issues related to global norms on environmental protection, human rights, labour standards and anti-corruption. The strategy may take the form of 'positive screening' or 'negative screening'. This strategy is often associated with the 'exclusion' strategy that eliminates potential investments in companies that fail to comply with international standards or conventions. Exclusions generally concern companies in such sectors as weapons (production and trade), tobacco, nuclear energy, pornography, gambling, alcohol and animal testing. The three strategies are the most frequent in investment decisions. The 'exclusion' strategy is dominant and, for example, covers over EUR 10 trillion of the total European professionally managed assets (Eurosif, 2016).

It is important to note that a key factor influencing investment decisions is transparency in reporting on $\mathrm{RI}$ to investors, which allows them to make assessments about what extent the RI principles and objectives are used in the company (Efama, 2016). The issue of identifying SRI funds can be problematic, because so far as socially responsible companies can report this in their financial reports or other reports, this information is difficult to find in the reports of investment funds. The investment portfolio of the fund can be very diverse, and the inclusion of detailed information on the social responsibility of all the companies in the portfolio is hardly practiced.

\section{Assessment of The Net Asset Value of SRI Funds Against All Investment Funds in Europe}

According to the reports analysing the pace of development of socially responsible enterprises, the 'concept of responsible investing has enormous potential' (KPMG, 2015). Based on the Efama report (2016), the net asset value of European investment funds amounted to EUR 14,142 billion in 2016, which represents an increase of more than 6\% compared to that in 2015 . By comparing the value of net assets from 2016 to 2011, a significant increase of $69 \%$ is noted. Against the backdrop of global data, Europe is the second largest to the USA investment fund market, with $48 \%$ and $33 \%$ shares in the world market at the end of 2016, respectively. The net asset value in the USA amounted for to EUR 19,674 billion in 2016 and increased by approximately $10 \%$ in comparison to 2015 . Other countries recorded a much lower net asset value in 2016: Brazil-EUR 1,544 billion, Australia-EUR 1,530 billion and Japan-EUR 1,385 billion. 
Data on the net asset value of the SRI investment funds in Europe in 2012-2016 against the background of the total value of the net assets of investment funds are presented in Table 1.

Table 1. Comparison of net assets of European Investment Funds and SRI European Investment Funds (EUR in billions) (Eurosif, 2016)

\begin{tabular}{llll}
\hline Net assets & $\mathbf{2 0 1 2}$ & $\mathbf{2 0 1 4}$ & $\mathbf{2 0 1 6}$ \\
\hline $\begin{array}{l}\text { 1. Net assets of European } \\
\text { investment funds }\end{array}$ & 9,468 & 12,030 & 14,142 \\
$\begin{array}{l}\text { 2. Net assets of SRI European } \\
\text { investment funds }\end{array}$ & 287 & 376 & 476 \\
\begin{tabular}{l} 
Share of 1 in 2 \\
\hline
\end{tabular} & $3.0 \%$ & $3.1 \%$ & $3.4 \%$ \\
\hline
\end{tabular}

The net asset value of European SRI funds was 476 EUR billion in 2016. The share of net assets of SRI funds in the total net assets of investment funds in Europe is systematically increasing and in 2016 it remained at the level of 3.4\%. Table 1 shows that the net asset value of the SRI funds increased by $26.6 \%$ in 2016 compared to that in 2015.

Analysing the data from the Eurosif report (Eurosif, 2016), an interesting trend of increasing net assets of SRI funds in favour of retail investors should be noted. In 2015, institutional investors held about $78 \%$ of SRI assets, compared to that in 2013 in which there was a drop of almost $19 \%$ of the assets held. The largest number of retail investors has been identified in Belgium - more than $60 \%$ of all assets.

In terms of asset allocation, equities comprise $30 \%$ of SRI assets and bonds represent $64 \%$ of SRI assets, which represents an increase of $24 \%$ in relation to that in 2013 . A detailed allocation of assets across countries is presented in Figure 1.

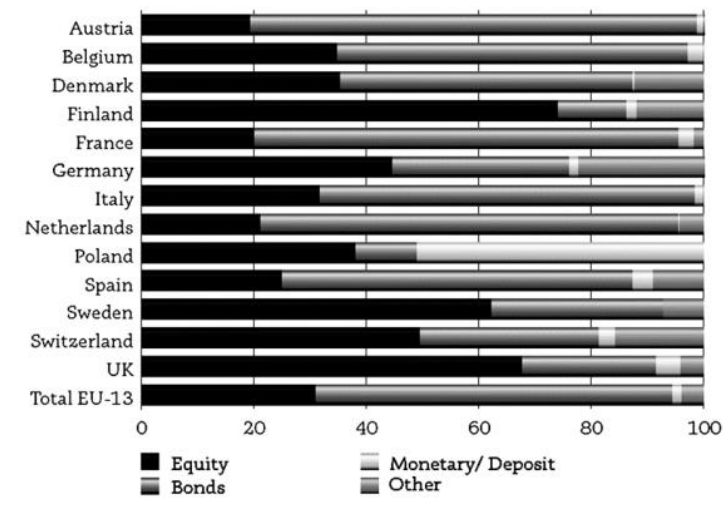

Figure 1. SRI assets allocation by country (Eurosif, 2016) 
Figure 2 presents a review of the strategies used by the European SRI funds for application of the identification and qualification strategies for SRIs.

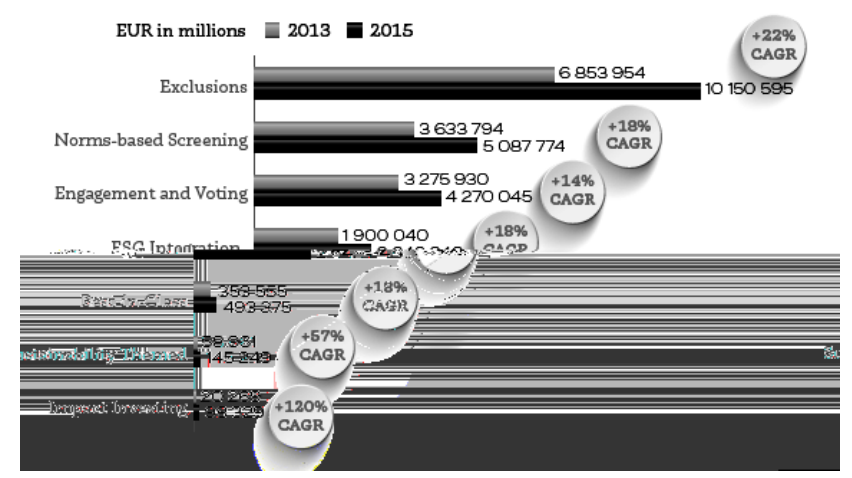

Figure 2. Overview of SRI strategies in Europe (Eurosif, 2016)

Figure 2 shows that the prevailing strategy of the SRI funds is the exclusions strategy, because of its clarity and ease of use.

\section{Analysis of SRI funds popularity in Poland}

Despite the development of the Polish capital market, the SRI market is still in a very early stage of growth. Poland has not been included in the cited Efama report in the 'Country specific developments' section, containing data from 14 European countries (Efama, 2016). On the other hand, the Eurosif report analysed the Polish SRI fund market for the first time as early as in 2012. According to the 2012 report, the assets of Polish funds classified as SRI funds amounted to PLN 5 billion (Eurosif, 2012). Market analyses and a few scientific studies on the socially responsible funds in 2012(Krupa, 2012) mentioned at least some socially responsible funds. The authors anticipated rapid development of the SRI funds in the future. Eurosif reports include, inter alia, data on other investment strategies used, as shown in Figure 3.

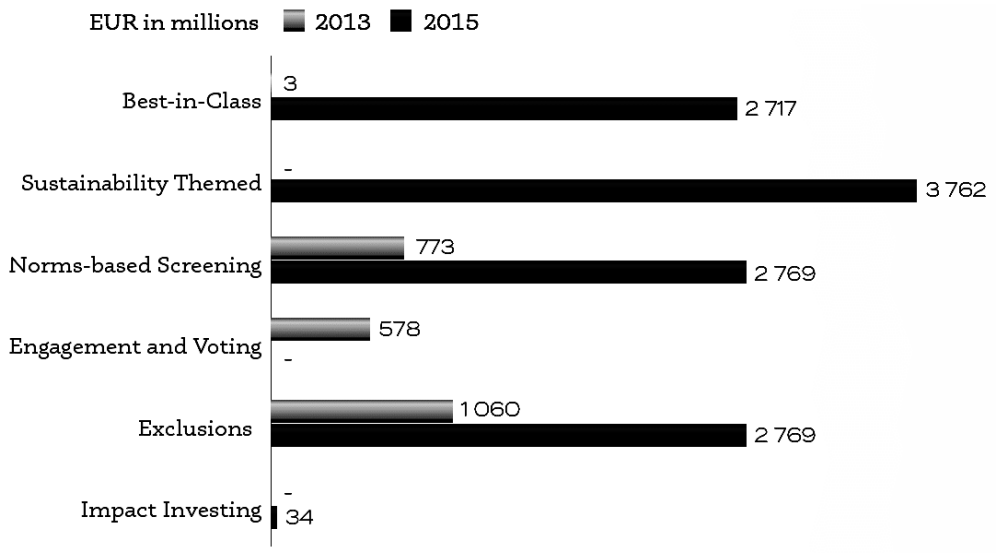

Figure 3. Overview of SRI strategies in Poland (Eurosif) 
However, in the Eurosif report of 2016, there presented a less optimistic opinion on Poland. According to the Eurosif report, the main reason for the low popularity of funds is a low demand for such investments due to distrust and lack of investor knowledge. It is not possible to determine which of the funds could become a leader, shaping a stable sector of SRI funds (Eurosif, 2016).

By 2013, the following SRI funds were present in Poland, as shown in Table 2.

Table 2. Net assets value of SRI funds in Poland (PLN in thousands) (Polish websites of investment funds)

\begin{tabular}{|c|c|c|c|c|c|c|}
\hline Name of the funds & Type & $\begin{array}{l}\text { December } \\
31,2012\end{array}$ & $\begin{array}{l}\text { December } \\
31,2013\end{array}$ & $\begin{array}{l}\text { December } \\
31,2014\end{array}$ & $\begin{array}{l}\text { December } \\
31,2015\end{array}$ & $\begin{array}{l}\text { December } \\
\text { 31, } 2016\end{array}$ \\
\hline $\begin{array}{l}\text { PKO Biotechnology } \\
\text { and Innovation }\end{array}$ & $\begin{array}{l}\text { Other foreign } \\
\text { shares }\end{array}$ & 5,615 & 80,059 & $2,52,289$ & $8,39,902$ & $8,46,459$ \\
\hline $\begin{array}{l}\text { PZU Energy, } \\
\text { Medicine, Ecology }\end{array}$ & $\begin{array}{l}\text { Foreign } \\
\text { sector shares }\end{array}$ & 0 & $1,450,068$ & $1,05,72,730$ & $64,91,011$ & $65,41,039$ \\
\hline SKOK FIO Ethical 1 & $\begin{array}{l}\text { Universal } \\
\text { Polish debt } \\
\text { securities }\end{array}$ & $\begin{array}{l}\text { No data } \\
\text { available }\end{array}$ & 7,985 & 7,985 & $\begin{array}{l}\text { No data } \\
\text { available }\end{array}$ & $\begin{array}{l}\text { No data } \\
\text { available }\end{array}$ \\
\hline SKOK FIO Ethical 2 & $\begin{array}{l}\text { Universal } \\
\text { Polish shares }\end{array}$ & 36,910 & 3,379 & $1,04,016$ & $1,09,973$ & $1,05,995$ \\
\hline $\begin{array}{l}\text { Climatic Change } \\
\text { Investor }\end{array}$ & $\begin{array}{l}\text { Foreign } \\
\text { sector shares }\end{array}$ & 799 & 1,392 & 1,388 & 2,522 & $\begin{array}{l}\text { No data } \\
\text { available }\end{array}$ \\
\hline
\end{tabular}


The largest Polish fund recognised as an SRI fund holds net assets of PLN 65,41,039, which is approximately the value of EUR 15,21,171. There was a strong increase in net assets of this fund in $2014-$ by $629 \%$ compared to that in 2013 . At the end of 2016, the net assets of this fund represented only $62 \%$ of the value at the end of 2014 . The net assets of other funds have a significantly lower value.

The net asset value of all investment funds in Poland was 275,015, 3 million PLN in 2016. The share of net assets of the SRI funds in the net asset value of all funds was $2.89 \%$ in 2016, which is very low. The highest net asset value of SRI funds was recorded in 2014, which was then $5.19 \%$ of the net asset value of all funds in Poland (GUS, Central Statistical Office of Poland). 
literature. Chun et al. (2012) did not prove statistically significant differences in the results of 'green funds' and conventional funds. Similar results were presented in Cortez, Silva and Areal (2009), Halbritter and Dorfleitner (2015) and Rathner (2012).

In Poland, there have been too few studies on the performance of SRI funds, whose results could encourage investment in such funds. According to the research in Lulewicz-Sas and Kilon (2014), where the financial performance of five investment funds with different strategies of 2009-2013 was analysed, the risk of investing in SRI funds was lower than the market risk over the same period. The authors only indicated one of the funds-PZU Energy, Medicine, Ecology-as a worthwhile investment, emphasising that the results are inconclusive.

The Eurosif Report of 2016 highlights the high level of economic growth in Poland, with a GDP growth rate of $3.6 \%$ in 2015, which is higher than the EU average, estimated at $1.9 \%$ (Eurosif, 2016). The capitalisation of the Warsaw Stock Exchange exceeded EUR 117 million. The Warsaw Stock Exchange as a member of the UN Sustainable Stock Exchanges promotes the principles of RI. Against the background of a well-developed capital market, the lack of active participation of investment funds in SRIs puzzles because the idea of SRI does not seem to be alien to the Warsaw Stock Exchange. Since 2009, there has been in operation the RESPECT index, bringing together companies that adhere to the highest environmental, social and corporate governance standards. In addition, the 'ESG Analysis of Companies in Poland' project is being implemented, aimed at boosting the SRI awareness and increasing the quantity and quality of the ESG disclosure. In the scope of legal regulations for entities that are not investment funds, there are no separate SRI regulations for funds in Poland, although each listed company at the Warsaw Stock Exchange should publish a statement on corporate governance in its annual report. The statement should remain in compliance with the Warsaw Stock Exchange Code of Corporate Governance: 'Best Practice of GPW Listed Companies 2016' (Warsaw Stock Exchange). Additionally, since 2009, socially responsible companies in Poland have been grouped in the RESPECT index. Currently, it consists of 24 companies with the highest liquidity, i.e., those representing WIG20, mWIG40 or sWIG80 indices. The final number of companies is chosen in a threestage selection; in addition to the liquidity issues, the company's corporate governance, information policy and investor relations are evaluated. The level of maturity of the company in terms of social responsibility is also verified.

\section{Conclusion}

In the era of dynamic development of financial markets, the qualification to have socially responsible funds may be an important prerequisite for the growth of investment funds. The net asset value of European SRI funds was 476 EUR billion in 2016. The share of net assets of SRI funds in the total net assets of investment funds in Europe is systematically increasing and in 2016 it remained at the level of $3.4 \%$. The data confirm that an activity consistent with the idea of social responsibility can be an important factor in making investment decisions. It would seem that the idea of social responsibility in Poland is well known. There is the RESPECT index that groups socially responsible companies since 2009. In 2016, the index was composed of 24 companies.

However, the scope of activity of SRI funds in Poland is very low. The highest net asset value of SRI funds was recorded in 2014, which was then $5.19 \%$ of the net asset value of all funds in Poland.

According to the author, the reason for such a state of affairs is the low awareness of investors in Poland, regarding the idea of social responsibility. The demand for this type of investment is low in Poland, which may be due to distrust and lack of knowledge of investors. Another reason for the low popularity of SRI funds in Poland is the insufficient scope of reporting of such funds. The investment policy of SRI funds is insufficiently presented both in the financial statements and in the prospectus of the funds, as well as on the websites of the Investment Fund Companies. The last premise of the low popularity of SRI funds in Poland, in the view of the author, is low expected effectiveness of these 
funds, although scientific research conducted worldwide and in Poland does not indicate significant differences in relation to the effectiveness of other investment funds.

\section{References}

Biadacz, R., \& Borowiec, L. (2017). Ethics in accounting in the context of corporate social responsibility, knowledge for market use 2017: people in economics-decisions, behaviour and normative models. In Proceedings of International Scientific Conference. Olomouc, Czech Republic. Retrieved September 10, 2017 from; http://knowledgeconference.upol.cz/downloads/2017-Knowledge for Market Use Proceedings.pdf

Borowski, G. (2011). Rynek funduszy inwestycyjnych w Unii Europejskiej. Warszawa, Poland: CEDEWU.

Cortez, M. C., Silva, F., \& Areal, N.(2009). The performance of European socially responsible funds. Journal of Business Ethics, 87(4), 573-588. Retrieved September 10, 2017 from; https://link.springer.com/article/ $10.1007 / \mathrm{s} 10551-008-9959-\mathrm{x}$

Efama (2016). Efama report on responsible investment. Brussels, Belgium. Retrieved September 10, 2017 from; https://www.efama.org/Publications/EFAMA Responsible\%20Investment\%20Report September\%20201 $\underline{6 . p d f}$

Eurosif (2012). European SRI study 2012. Brussels, Belgium. Retrieved September 10, 2017 from; https://www.eurosif.org/sri-study-2012

Eurosif (2016). European SRI study 2016. Brussels, Belgium. Retrieved September 10, 2017 from; https://www.eurosif.org/sri-study-2016

GUS (2015) Central Statistical Office of Poland, Investment funds statistics. Retrieved September 10, 2017 from; http://www.gus.pl

Haigh, M., \& Hazelton, J. (2004). Financial markets: a tool for social responsibility? Journal of Business Ethics, 52(1), 59-71. Retrieved September 10, 2017 from Proquest.

Halbritter, G., \& Dorfleitner, G. (2015). The wages of social responsibility-where are they? a critical review of ESG investing. Review of Financial Economics, 26, 25-35. Retrieved September 10, 2017 from; https://doi.org/10.1016/i.rfe.2015.03.004

Humphrey, J. E., \& Lee, D. D. (2011). Australian socially responsible funds: performance, risk and screening intensity. Journal of Business Ethics, 102, 519-535. Retrieved September 10, 2017 from Proquest.

Ito, Y., Managi, S., \& Matsuda, A. (2013). Performances of socially responsible investment and environmentally friendly funds. Journal of the Operational Research Society, 64, 1583-1594. Retrieved September 10, 2017 from Proquest.

Khorana, A., Servaes, H., \& Tufano, P. (2005). Explaining the size of mutual funds industry around the world. Journal of Financial Economics, 78(1), 145-185. Retrieved September 10, 2017 from; http://faculty.london.edu/hservaes/ife2005.pdf

KPMG (2015). European responsible investing fund survey 2015. Luxembourg. Retrieved September 10, 2017 from; $\quad$ https://home.kpmg.com/lu/en/home/insights/2015/03/european-responsible-investing-fundsurvey-2015.html

Krupa, D. (2012). Fundusze inwestycyjne odpowiedzialne społecznie. Annales Universitatis Mariae CurieSkłodowska, 46(1), 307-316.

Lulewicz-Sas, A., \& Kilon, J. (2014). Analysis of the effectiveness of socially responsible investment funds in Poland. Economics and Management, 19(4), 338-345. Retrieved September 10, 2017 from; http://dx.doi.org/10.5755/i01.em.19.4.8101.

Mallett, J. E., \& Michelson, S. (2010). Green investing: is it different from socially responsible investing. International Journal of Business, 15(4), 395-410.

Polish websites of investment funds (2016). Retrieved September 10, 2017 from; http://www.pkotfi.pl, http://www.pzu.pl, http://www.analizy.pl, http:// www.tfiskok.pl, http://www.altustfi.pl 
Rathner, S. (March, 2012). The performance of socially responsible investment funds: a meta-analysis. Austria: University of Salzburg. Retrieved from; http://www.uni-salzburg.at/fileadmin/oracle file imports/ 1759214.PDF.

Regulation of the Minister of Finance of 24 December 2007 on special accounting rules for investment funds. Journal of Laws, 249(1859). Retrieved September 10, 2017 from; http://www.isap.sejm.gov.pl

Sakuma, K., \& Louche, C. (2008). Socially responsible investment in Japan: Its mechanism and drivers. Journal of Business Ethics, 82, 425-448. doi:10.1007/s10551-008-9895-9

Utz, S., \& Wimmer, M. (2014). Are they any good at all? a financial and ethical analysis of socially responsible mutual funds. Journal of Asset Management, 15(1), 72-82. Retrieved September 10, 2017 from Proquest.

Warsaw Stock Exchange (2015). Retrieved September 10, 2017 from; http://www.gpw.pl

Zamojska, A. (2012). Efektywność funduszy inwestycyjnych w Polsce. Studium teoretyczno-praktyczne. Wydawnictwo. Warszawa, Poland: C.H. Beck. 